\title{
Analisis dan Perancangan Sistem Informasi Pembelian, Penjualan dan Persediaan pada UD. Parjuma Sonari
}

\author{
${ }^{1}$ Raelida Turnip, ${ }^{2}$ Rin Rin Meilani Salim, ${ }^{3}$ Handoko \\ Universitas Mikroskil \\ Medan, Indonesia \\ 1712111879@students.mikroskil.ac.id, 2rinrin.meilani@mikroskil.ac.id, \\ ${ }^{3}$ handoko.wu@mikroskil.ac.id
}

*Corresponding Author

Diajukan $\quad: 11 / 10 / 2021$

Diterima $\quad: 12 / 10 / 2021$

Dipublikasi $\quad: 18 / 10 / 2021$

\begin{abstract}
ABSTRAK
Perkembangan teknologi yang begitu pesat dan persaingan bisnis yang semakin ketat memaksa suatu perusahaan menggunakan teknologi yang mampu mendukung kegiatan aktivitas kerja dengan cepat dan tepat. UD. Parjuma Sonari adalah salah satu perusahaan dagang yang melakukan pembelian, penjualan, dan pencatatan persediaan obat-obatan tani. Pada saat ini, proses bisnis yang berjalan pada UD. Parjuma Sonari masih melakukan pencatatan berbasis kertas yang menghambat proses bisnis yang berjalan. Penelitian ini bertujuan menganalisis dan merancang sistem informasi pembelian, penjualan, persediaan barang yang dapat mendukung proses operasional perusahaan. Metodologi yang digunakan dalam analisis dan perancangan ini adalah metodologi SDLC (System Development Life Cycle). Sistem informasi yang dirancang berbasis desktop menggunakan Microsoft Visual Studio 2015 dan SQL Server 2014. Rancangan proses menggunakan DFD (Data Flow Diagram). Hasil dari penelitian ini dapat disimpulkan bahwa analisis dan perancangan sistem informasi UD. Parjuma Sonari berguna sebagai rekomendasi terhadap sistem kedepannya yang dapat dijadikan sebagai landasan untuk pengembangan sistem usulan.
\end{abstract}

Kata Kunci: pembelian, penjualan, persediaan, sistem informasi

\section{PENDAHULUAN}

Sistem informasi mempunyai peranan yang sangat penting, semakin pesat perkembangan suatu perusahaan maka sistem informasinya juga mempunyai peranan yang semakin penting. Dampak yang mungkin terjadi jika dalam perusahaan belum menerapkan sistem informasi dapat menghasilkan laporan yang kurang akurat, kesalahan dalam pencatatan data serta pengulangan data.

Pada objek penelitian, UD. Parjuma Sonari belum merasakan dampak positif penerapan sistem informasi, sehingga informasi yang diberikan oleh perusahaan belum maksimal. UD. Parjuma Sonari merupakan salah satu perusahaan dagang yang melakukan penjualan, pembelian, dan pencatatan persediaan obat-obatan tani. Dalam operasional bisnisnya, UD. Parjuma Sonari mengalami kendala yaitu dalam proses pencatatan persediaan, penjualan, dan pembelian yang masih menggunakan pencatatan yang sederhana di dalam buku dan belum tertata dengan rapi. Sistem Informasi yang belum ada dan masih menggunakan pencatatan data di buku membuat UD. Parjuma Sonari sulit mengetahui hutang yang belum dilunasi.

Dalam proses penjualan barang, pemilik juga mengalami kendala dimana ketika hendak melakukan penjualan, pemilik harus melakukan pengecekan langsung stock persediaan di gudang terlebih dahulu atas 
permintaan pelanggan yang bisa memakan waktu cukup lama. Faktur penjualan yang masih menggunakan catatan di kertas juga membuat pemilik jadi lebih sulit mengetahui barang yang belum atau sudah diterima pelanggan. Pencatatan persediaan yang tidak sesuai dengan aktivitas perusahaan yang terjadi dan tidak dapat melihat stok langsung secara up to date akan mempengaruhi penjualan barang dagangan, sehingga dapat menyebabkan pencatatan persediaan berbeda dengan persediaan yang sebenarnya di gudang.

Mengingat UD. Parjuma Sonari saat ini belum cukup siap untuk mengembangkan sebuah sistem informasi khususnya persiapan finansial dan sumber daya manusia maka sistem informasi ini hanya sampai pada tahap analisis dan perancangan sistem. Hal ini dilakukan agar perusahaan memiliki waktu yang cukup untuk memahami rancangan sistem yang diusulkan. Rancangan ini akan memberikan gambaran kepada pemilik UD. Parjuma Sonari dimana jika rancangan ini dikembangkan maka sistem informasi akan membantu pemilik UD. Parjuma Sonari dalam mengelola transaksi sehari-hari dan menghasilkan laporan pembelian, penjualan dan persediaan.

\section{PENELITIAN TERDAHULU Sistem Informasi}

Anggraeni, E. Y. (2017) mendefinisikan sistem informasi sebagai suatu sistem yang memfasilitasi level manajemen dalam memberikan informasi yang mendukung dalam operasional bisnis dan pengambilan keputusan. Anggraeni, E. Y. (2017) juga menyatakan bahwa sistem informasi ini menerima, menyimpan, memroses dan mengkomunikasikan data menjadi informasi dengan menggunakan bantuan dari Teknologi Informasi.

Wardana, P., Nugraha, A. E., \& Herwanto, D. (2021) menyatakan bahwa sistem informasi yang baik adalah sistem yang mampu mendukung kegiatan-kegiatan operasional dari perusahaan, dimana harus memberikan proses yang efisien. Selain itu, dengan adanya penerapan sistem informasi, maka proses bisnis mulai dari pendataan, pemrosesan dan pelaporan akan menjadi lebih efektif dan efisien (Saefudin,
Yulikomalasari, \& Arianti, 2020). Selain itu, Nurfi (2020) menyatakan bahwa dengan menggunakan sistem informasi dapat mengurangi perlambatan proses dalam pengelolaan data dan pengendalian stok barang.

\section{Data Flow Diagram}

Data Flow Diagram (DFD) merupakan diagram yang cocok digunakan dalam pemodelan perangkat lunak yang akan diimplementasikan dengan menggunakan pemrograman terstruktur karena pemrograman terstruktur membagi-bagi bagiannya dengan fungsi fungsi dan prosedur (Sukamto \& Shalahudin , 2018). Sukamto \& Shalahudin (2018) juga menyatakan bahwa Data Flow Diagram (DFD) merupakan diagram yang menggambarkan kegiatan-kegiatan atau aliran data yang ada dalam suatu sistem.

Kendall, K. E., \& Kendall, J. E. (2014) menyatakan bahwa Data Flow Diagram merupakan alat yang digunakan pada metodologi pengembangan sistem yang terstuktur (Structured Analysis and Design). DFD sering digunakan untuk menggambarkan suatu sistem yang telah ada atau sistem baru yang akan dikembangkan secara logika dengan menggunakan notasinotasi untuk menggambarkan arus dari data sistem

\section{System Development Life Cycle}

Kendall, K. E., \& Kendall, J. E. (2014) mendefinisikan siklus hidup pengembangan sistem sebagai pendekatan yang diterapkan secara bertahap guna menganalis dan mendesain sistem dimana sistem yang dirancanga dapat dikembangkan menjadi sistem yang layak diimplementasikan pada perusahaan dengan menyesuaikan dengan kebutuhan pemakai sistem dengan spesifik.

Kendall, K. E., \& Kendall, J. E. (2014) juga menyatakan bahwa pada setiap bagian dari siklus ini dibagi menjadi tahapan kerja yang memiliki karakteristik tersendiri. Tahapan lengkap dari SDLC terdiri dari 7 fase yaitu mengidentifikasikan masalah, peluang, dan tujuan, menentukan syaratsyarat informasi, menganalisis kebutuhan sistem, merancang sistem yang direkomendasikan, mengembangkan dan mendokumentasi perangkat lunak, menguji 
dan mempertahankan sistem dan mengimplementasikan dan mengevaluasi sistem.

\section{METODOLOGI}

Metodologi yang digunakan oleh penulis adalah SDLC (System Development Life Cycle) dimana penulis mengerjakan hinga fase ke 4 dari 7 fase, berikut:

1. Mengidentifikasi masalah, peluang dan tujuan

a. Merumuskan permasalahan penjualan, pembelian dan persediaan yang ada pada UD. Parjuma Sonari.

b. Mengidentifikasi peluang yang mungkin akan didapatkan UD. Parjurma Sonari ketika menerapkan sistem informasi.

c. Mengidentifikasi tujuan penggunaan sistem informasi dalam proses operasional bisa lebih efektif dan efisien.

2. Menentukan syarat-syarat informasi

a. Menganalisis dokumen masukan dan keluaran pada sistem berjalan untuk kegiatan penjualan, pembelian, persediaan.

b. Menganalisis proses sistem berjalan dalam bentuk DFD (Data Flow Diagram).

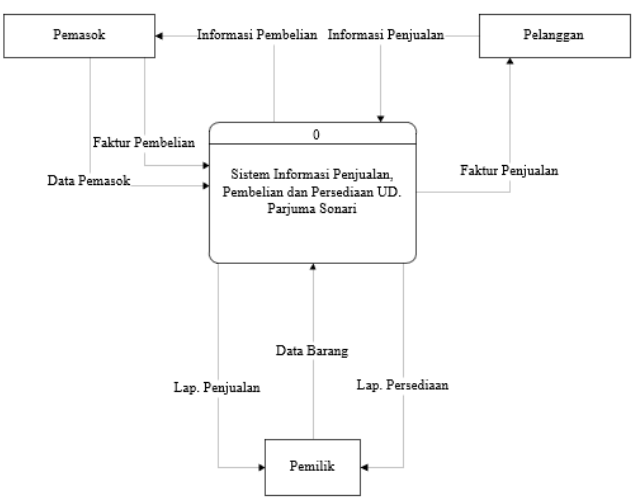

Gambar 1. DFD Sistem Berjalan pada UD. Parjuma Sonari

3. Menganalisis kebutuhan sistem

a. Menggambarkan sistem usulan dengan menggunakan DFD (Data Flow Diagram).

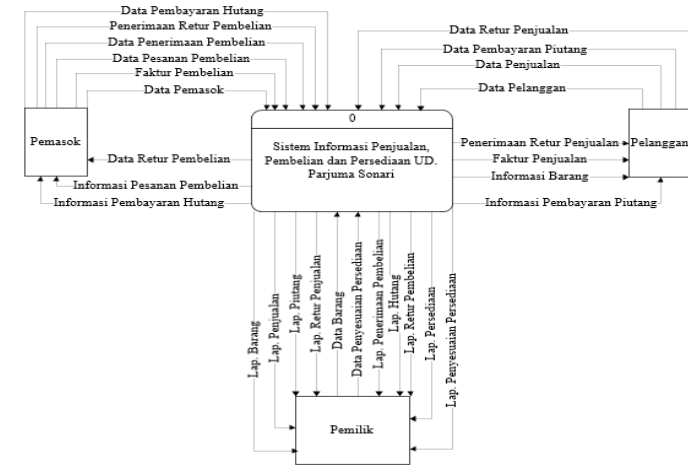

Gambar 2. DFD Sistem Usulan pada UD. Parjuma Sonari

b. Menganalisis keputusan terstruktur yang dibuat dan merancang kamus data.

4. Merancang sistem yang direkomendasikan

a. Merancang sistem input dengan menggunakan Micrososft Visual Studio 2015

b. Merancang sistem output dengan Crystal Report

c. Melakukan normalisasi

d. Merancang basis data menggunakan Microsoft SQL Server 2014

\section{PEMBAHASAN DAN HASIL}

Berikut ini beberapa hasil perancangan sistem informasi pembelian, penjualan dan persediaan pada UD. Parjuma Sonari:

1. Form Data Barang yang digunakan untuk menginput barang-barang yang terdapat pada toko

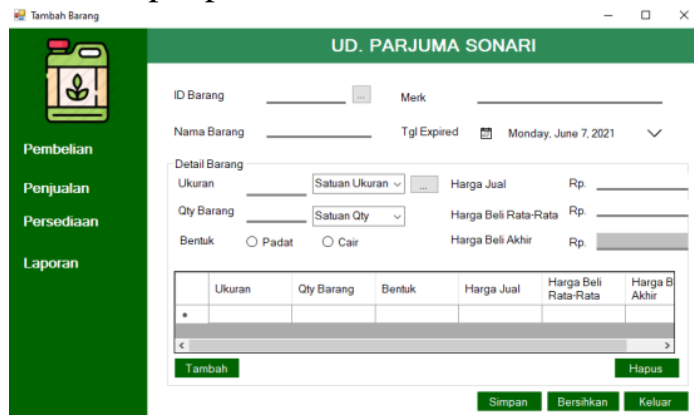

Gambar 3. Form Data Barang

2. Form Data Pesanan Pembelian yang digunakan untuk mencatat transaksi pesanan pembelian kepada pemasok. Form digunakan ketika toko memesan barang kepada pemasok. 


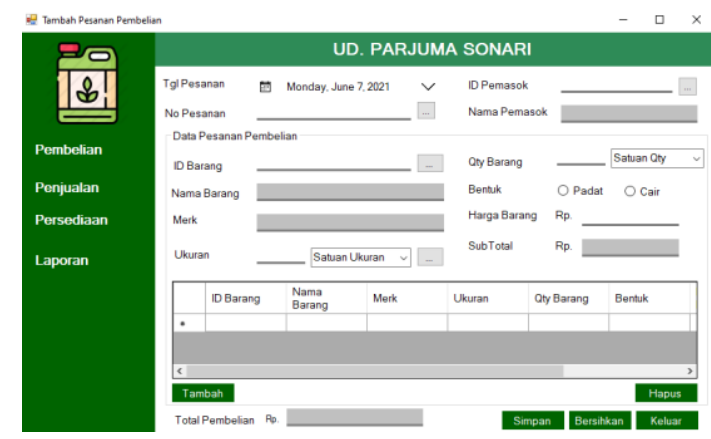

Gambar 4. Form Data Pesanan Pembelian

3. Form Penerimaan Barang yang digunakan untuk mencatat penerimaan atas pembelian barang dari pemasok. Form ini digunakan ketika menerima barang atau kiriman dari pemasok. Ketika pengguna menginput barang yang diterima pada form ini maka otomatis stok barang akan ikut bertambah.

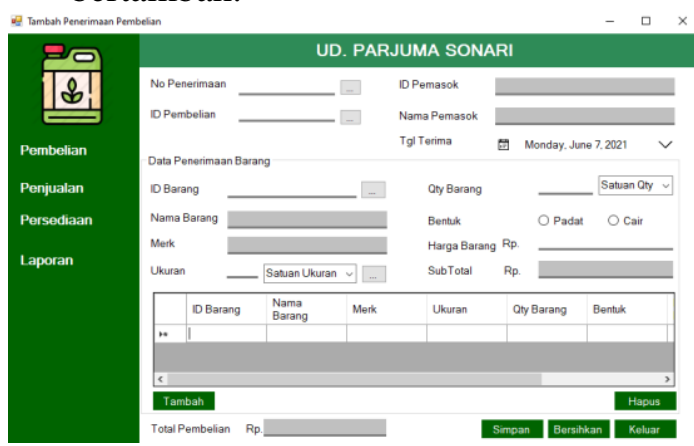

Gambar 5. Form Penerimaan Barang

4. Form Retur Pembelian yang digunakan untuk menginput retur pembelian kepada pemasok.

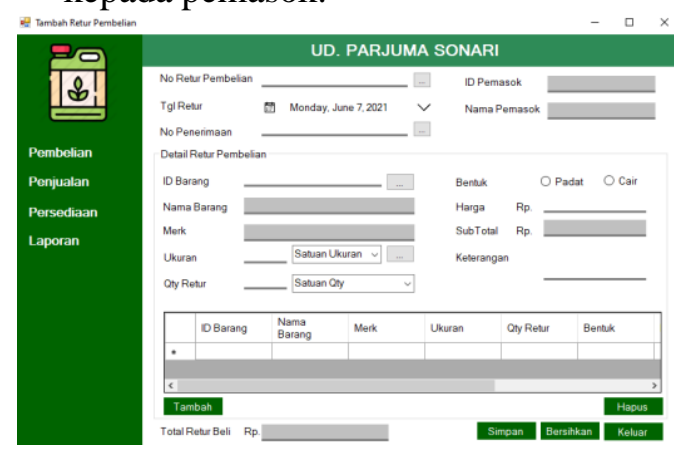

Gambar 6. Form Retur Pembelian

5. Form Penjualan yang digunakan untuk menginput penjualan kepada pelanggan. Ketika penjualan terjadi maka stok barang akan otomatis berkurang.

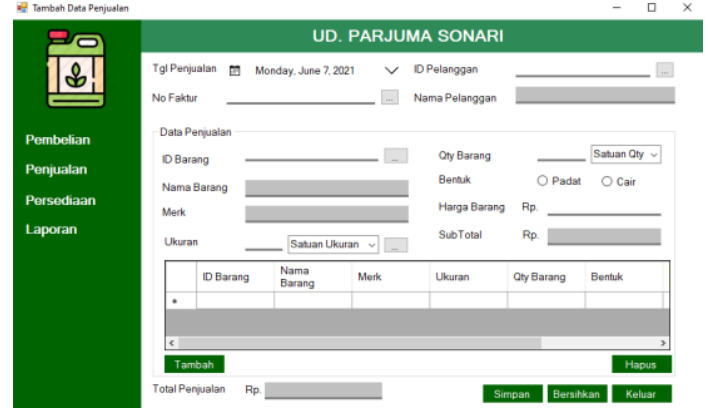

Gambar 7. Form Penjualan

6. Form Retur Penjualan yang digunakan untuk menginput Retur penjualan dari pelanggan.

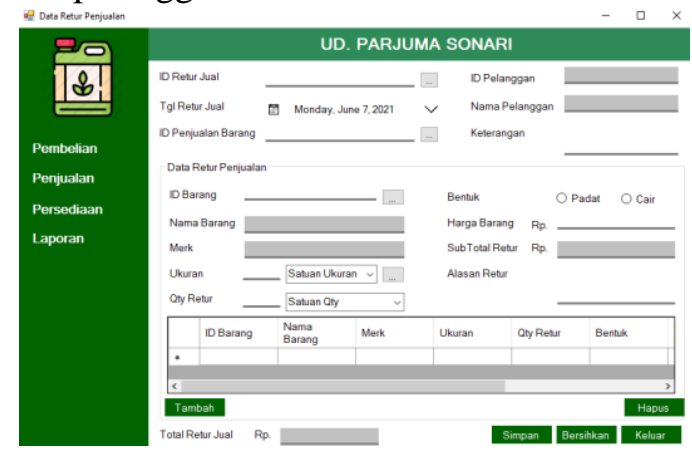

Gambar 8. Form Retur Penjualan

7. Penyesuaian Persediaan yang digunakan untuk menyesuaikan stok ketika terjadi perbedaan antara stok fisik dengan stok di komputer.

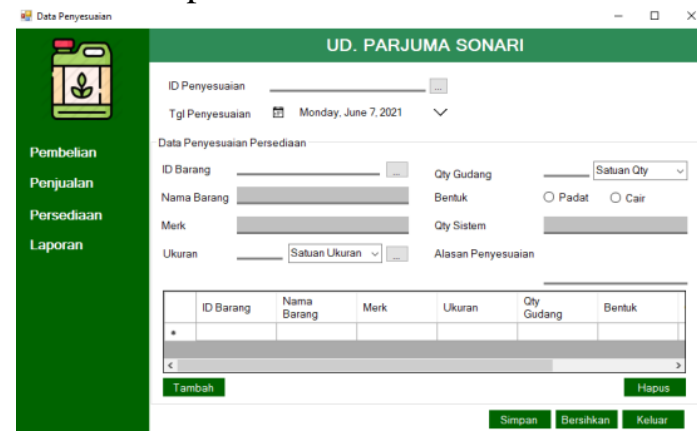

Gambar 9. Form Penyesuaian Persediaan

8. Laporan barang yang berfungsi untuk menampilkan informasi barang beserta stok-nya. 


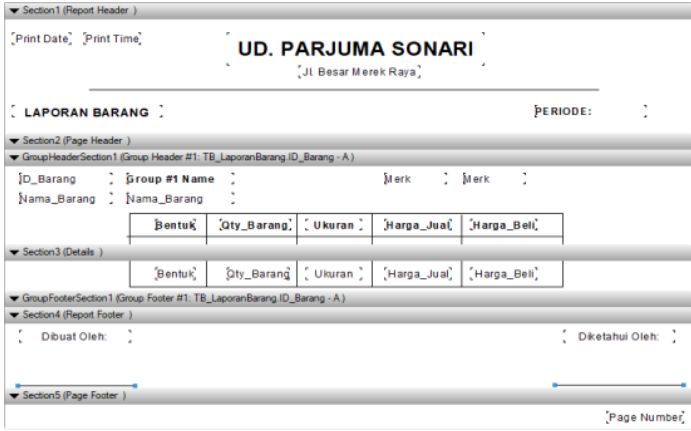

Gambar 10. Laporan Barang

9. Laporan Penjualan yang berfungsi untuk menampilkan detail penjualan yang terjadi pada rentang waktu tertentu beserta barang pada transaksi penjualan tersebut.

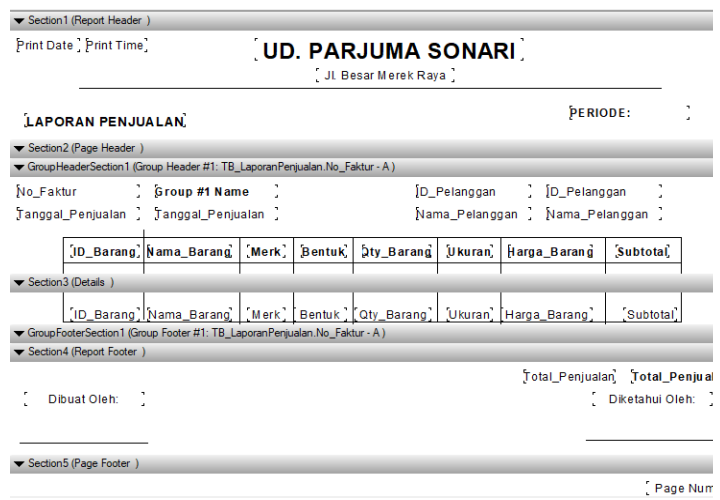

Gambar 11. Laporan Penjualan

10. Laporan Retur Penjualan yang berfungsi untuk menampilkan detail retur penjualan yang terjadi pada rentang waktu tertentu beserta barang pada transaksi retur penjualan tersebut.

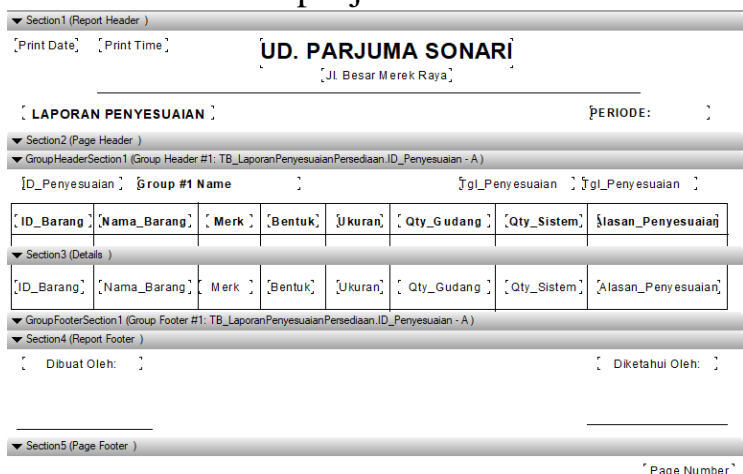

Gambar 12. Laporan Retur Penjualan

11. Laporan Penerimaan Pembelian yang berfungsi untuk menampilkan detail penerimaan atas pembelian dari pemasok.

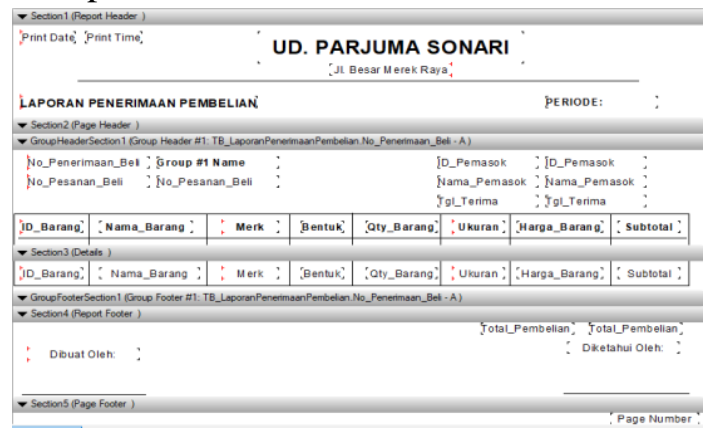

Gambar 13. Laporan Penerimaan Pembelian

12. Laporan Retur Pembelian yang berfungsi untuk menampilkan detail retur pembelian yang terjadi pada rentang waktu tertentu beserta barang pada transaksi retur pembelian tersebut.

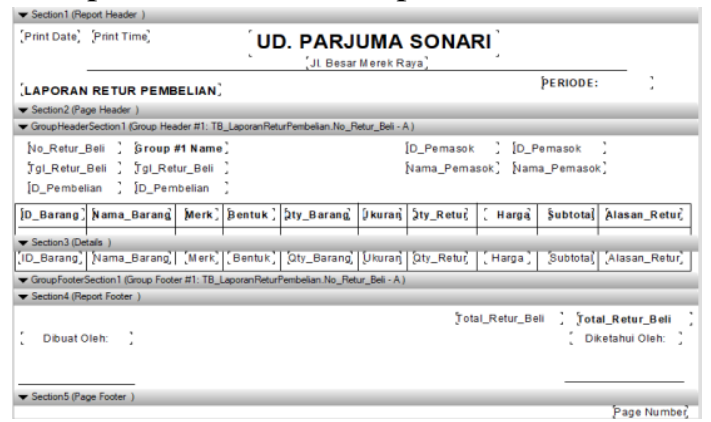

Gambar 14. Laporan Retur Pembelian

13. Informasi pembayaran hutang berfungsi untuk menampilkan sisa hutang dan tanggal jatuh tempo.

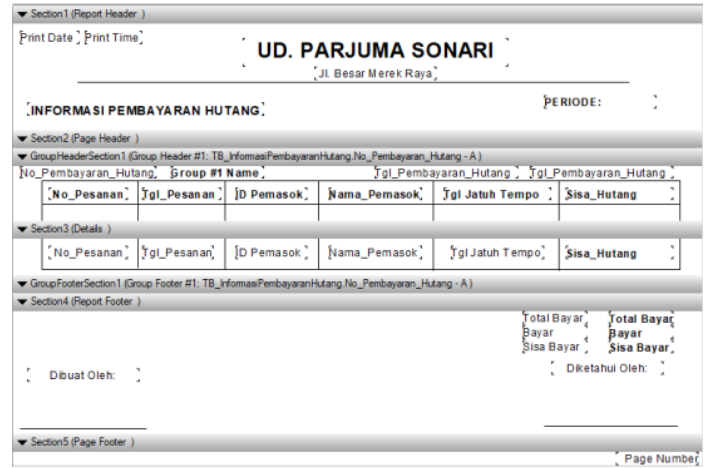

Gambar 15. Informasi pembayaran hutang

14. Faktur Penjualan yang akan dicetak dan diberikan kepada pelanggan atas bukti transaksi penjualan yang terjadi. 


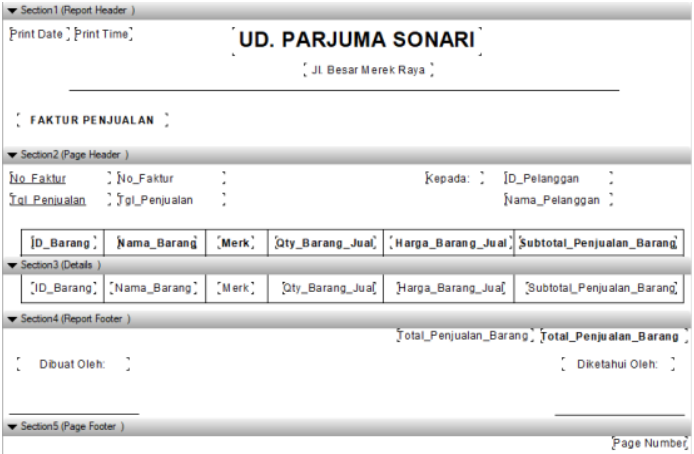

Gambar 16. Faktur Penjualan

\section{KESIMPULAN}

Setelah menyelesaikan proses analisis dan perancangan sistem informasi pada UD. Parjuma Sonari, maka dapat disimpulkan jika sistem usulan ini dikembangkan maka dapat membantu menyediakan informasi hutang dan piutang dan menyediakan informasi persediaan secara up to date.

Adapun saran yang ingin penulis sampaikan adalah:

1. Sistem usulan yang dirancang pada penelitian ini dapat dikembangkan, sehingga diharapkan nantinya dapat memberikan kemudahan pada UD. Parjuma Sonari dalam melakukan pencatatan pembelian, penjualan dan persediaan.

2. Sistem usulan dapat dikembangkan lagi dengan menampilkan laporan total laba rugi, sehingga pemilik dapat mengetahui total pendapatan pada UD. Parjuma Sonari.

\section{REFERENSI}

Anggraeni, E. Y. (2017). Pengantar sistem informasi. Penerbit Andi.

Kendall, K. E., \& Kendall, J. E. (2014). Systems analysis and design, NJ: Pearson Prentice Hall.

Nurfi , S. (2020). Sistem Informasi Inventori Barang Pada CV. Putra Karya Baja Dengan Metode Waterfall. BINA INSANI ICT JOURNAL, Vol 7(2), 145-155.

Saefudin, D. F., Yulikomalasari, \& Arianti, D. (2020). PERANCANGAN SISTEM INFORMASI PERSEDIAAN BARANG PADA PT BINA SAN PRIMA KARAWANG. JURNAL TEKNOLOGI DAN OPEN SOURCE, 158-175.

Sukamto, R. A., \& Shalahudin, M. (2018). Rekayasa Perangkat Lunak. Bandung: Informatika Bandung.

Wardana, P., Nugraha, A. E., \& Herwanto, D. (2021). Rancangan Sistem Informasi Inventori Berbasis Web PT. Indotaise Karawang. INTECOMS: Journal of Information Technology and Computer Science, 4(2), 155-168. 
